\section{Identifying Volatiles in Soursop and Comparing Their Changing Profiles during Ripening}

\author{
Wayne T. Iwaoka and Xiaorong Zhang \\ Department of Food Science and Human Nutrition, University of Hawaii at \\ Manoa, Honolulu, HI 96822
}

Richard A. Hamilton

3242 Pawaina Street, Honolulu, HI 96822

\section{C.L. Chia}

Department of Horticulture, University of Hawaii at Manoa, Honolulu, HI 96822

\section{C.S. Tang \\ Department of Agricultural Biochemistry, University of Hawaii at Manoa, Honolulu, HI 96822}

Additional index words. Annona muricata, (Z) -3-hexen-1-ol, methyl butanoate, methyl (E)2-butenoate, methyl hexanoate, methyl (E) -2-hexenoate

Abstract. The volatile compounds in soursop (Annona muricata L.) were obtained by a liquid-liquid continuous extraction procedure from the aqueous solution of blended soursop pulp and analyzed by gas chromatography (GC) and GC-mass spectrometry (MS). Twelve volatiles were identified by comparing their mass spectra and Kovats retention indexes with those of standard compounds: five were identified tentatively from MS data only, eight are being reported for the first time. $(Z)$-3-hexen-l-ol was the main volatile present in mature-green fruit, while methyl $(E)$-2-hexenoate, methyl $(E)$-2butenoate, methyl butanoate, and methyl hexanoate were the four main volatiles present in ripe fruit. Concentrations of these five volatiles decreased and several other unidentified volatiles appeared when the fruit became overripe.

There has been an increased number of exotic tropical fruit, such as papaya, mango, and carambola, appearing on supermarket shelves in the United States and western Europe. As familiarity with the novel taste of these fruit increases, demand for them is likely to increase in the future for fresh and processed products. Soursop has a unique, pleasant aroma and an intriguing sweet-sour flavor (Morton, 1966). The fruit have been used in products such as tropical fruit drinks, sherbert, ice cream, jams, and jellies. Most research on soursop has dealt with nutritional composition and physical and chemical changes during ripening (Gebhardt et al., 1982; Paull, 1982; Wenkam and Miller, 1965). MacLeod and Pieris (1981a) and Paull et al. (1983) have analyzed the aroma components of ripe soursop, but there has been little work on the changes in volatiles in soursop fruit after har-

\footnotetext{
Received for publication 26 May 1992. Accepted for publication 20 Mar. 1993. Trade names are used for information purposes only. We thank Karl Yanagihma for his help with the gas chromatograph-mass spectrometry analysis, Philip Ito for providing fruit from the Waiakea Experiment Station, and Roland Wong for his technical assistance. The cost of publishing this paper was defrayed in part by the payment of page charges. Under postal regulations, this paper therefore must be hereby marked advertisement solely to indicate this fact.
}

natant was decanted. The extraction procedure was repeated with $300 \mathrm{ml}$ of distilled water and the supernatants were combined. The volatiles were extracted for $24 \mathrm{~h}$ with methylene chloride in a liquid-liquid continuous extractor. The methylene chloride fraction was dried with sodium sulfate and the volatiles were concentrated to $2 \mathrm{ml}$ on a KudernaDanish concentrator (Kontes, Vineland, N.J.) with a Snyder column. The extract was concentrated further to $1 \mathrm{ml}$ by slowly flushing it with purified $\mathrm{N}$ at $20 \mathrm{C}$. The essence concentrate was stored at $-40 \mathrm{C}$.

Gas chromatography (GC). A Hewlett Packard (HP, Avondale, Pa.) 5890 gas chromatography containing a flame ionization detector (FID) and a nitrogen-phosphorus detector (NPD) was used with an HP Ultra-1 capillary column $(50 \mathrm{~m} \times 0.31 \mathrm{~mm} \times 0.17 \mu \mathrm{m})$. The GC conditions for FID analysis were detector, $250 \mathrm{C}$; injector, $250 \mathrm{C}$; oven, isothermal for 4 min at $30 \mathrm{C}$, then programmed to $210 \mathrm{C}$ at $2 \mathrm{C} /$ min, helium carrier gas flow rate, $0.91 \mathrm{ml} \cdot \mathrm{min}$ with a column head pressure of $110 \mathrm{kPa}$. The GC conditions for NPD were the same as for FID, except that the detector temperature was set at 275C. An IBM (Armonk, N. Y.) PS/2 model $50 \mathrm{Z}$ computer and a Perkin Elmer Nelson Systems (Cupertino, Calif.) PC integrator software (revision 5.0) were used to process the GC data.

$G C$-mass spectrometry (GC-MS). An HP 5890 gas chromatography coupled to an HP 5970 mass selective detector (MSD) with an HP 5970A GC/MS/data system and a DB-1 capillary column (J\&W Scientific, Folsom, Calif.) $(30 \mathrm{~m} \times 0.25 \mathrm{~mm} \times 0.25 \mu \mathrm{m})$ were used for the GC-MS analysis. The GC conditions were the same as above, except that the flow rate of the carrier gas was $1.23 \mathrm{ml} \cdot \mathrm{min}^{-1}$ with a column head pressure of $69 \mathrm{kPa}$. The ionization voltage (electron impact mode) was 70 $\mathrm{eV}$.

Standard compounds. Standards were obtained from commercial sources. Volatiles were identified by comparing their mass spectra and retention indexes (RIs) with those of standard compounds. The Kovats RI (Ettre, 1964) also was used for identification.

The essence concentrate obtained from the methylene chloride extraction of ripe soursop (on day 5) had a strong aroma characteristic of soursop. Seventeen compounds were identified or tentatively identified with their GC retention data, Kovats RI, and relative peak areas (Table 1). Twelve volatiles were identified by GC-MS and the Kovats RI. Five volatiles were tentatively identified based on comparisons of mass spectra with literature spectra (Stein, 1987).

Of the volatiles identified, three are being reported for the first time for soursop: methyl pentanoate, linalool, and methyl 2,4hexadienoate. The others were identified by MacLeod and Pieris (1981a) and Paull et al. (1983). Volatiles tentatively identified for the first time in soursop included 2-methyl-2butanol, 1-methylethyl 2-butenoate, methyl 2hydroxy-3-methylpentanoate, 4-methylbenzaldehyde, and methyl 3-phenyl-2-propenoate.

The occurrence of some of these volatiles 
Posthafvest Biology and Technology

Table 1. Lemon juice composition at harvest and after 8 weeks of storage under various conditions.

\begin{tabular}{|c|c|c|c|c|c|c|c|}
\hline \multirow[b]{2}{*}{ Treatment ${ }^{y}$} & \multicolumn{7}{|c|}{ Chemical constituents } \\
\hline & $\begin{array}{c}\text { Extractable } \\
\text { juice }^{x}\end{array}$ & $\begin{array}{c}\mathrm{SSC}^{2} \\
\text { (\% juice) }\end{array}$ & $\mathrm{pH}$ & $\begin{array}{l}\text { Acidity } \\
\text { (\% juice) }\end{array}$ & $\begin{array}{c}\text { Ascorbic } \\
\text { acid } \\
\text { (mg/100 ml juice) }\end{array}$ & $\begin{array}{l}\text { Reducing } \\
\text { sugars } \\
\text { (\% juice) }\end{array}$ & $\begin{array}{l}\text { Nonreducing } \\
\text { sugars } \\
\text { (\% juice) }\end{array}$ \\
\hline \multicolumn{8}{|c|}{ Cold storage } \\
\hline A $(2 C)$ & $45.3 \mathrm{c}$ & $8.6 \mathrm{c}$ & $2.3 \mathrm{~b}$ & $6.6 \mathrm{de}$ & $49.2 \mathrm{a}-\mathrm{c}$ & $1.2 \mathrm{e}$ & $0.8 \mathrm{e}$ \\
\hline $\mathrm{B}(8 \mathrm{C})$ & $49.2 \mathrm{ab}$ & $8.9 \mathrm{a}-\mathrm{c}$ & $2.4 \mathrm{ab}$ & $6.2 \mathrm{~g}$ & $49.5 \mathrm{a}-\mathrm{c}$ & $1.5 \mathrm{de}$ & $0.9 \mathrm{~d}$ \\
\hline $\mathrm{C}(13 \mathrm{C})$ & $49.5 \mathrm{a}$ & $9.2 \mathrm{a}-\mathrm{c}$ & $2.3 \mathrm{~b}$ & $6.3 \mathrm{fg}$ & $49.0 \mathrm{a}-\mathrm{c}$ & $1.5 \mathrm{de}$ & $1.0 \mathrm{~d}$ \\
\hline E & 46.3 be & $9.3 \mathrm{ab}$ & $2.3 \mathrm{~b}$ & $7.0 \mathrm{ab}$ & $50.1 \mathrm{a}-\mathrm{c}$ & $1.7 \mathrm{~cd}$ & $1.0 \mathrm{~d}$ \\
\hline $\mathrm{F}$ & $49.9 \mathrm{a}$ & $9.4 \mathrm{a}$ & $2.4 \mathrm{ab}$ & $6.7 \mathrm{c}-\mathrm{e}$ & $52.4 \mathrm{a}$ & $1.5 \mathrm{de}$ & $0.9 \mathrm{~d}$ \\
\hline G & $47.6 \mathrm{a}-\mathrm{c}$ & $8.6 \mathrm{c}$ & $2.5 \mathrm{a}$ & $6.5 \mathrm{ef}$ & $50.1 \mathrm{abc}$ & $1.4 \mathrm{de}$ & $1.0 \mathrm{~d}$ \\
\hline $\mathrm{H}$ & $46.4 \mathrm{bc}$ & $9.2 \mathrm{a}-\mathrm{c}$ & $2.4 \mathrm{ab}$ & $7.1 \mathrm{a}$ & $49.5 \mathrm{a}-\mathrm{c}$ & $1.7 \mathrm{~cd}$ & $1.1 \mathrm{c}$ \\
\hline \multicolumn{8}{|c|}{$\mathrm{CO}$, for $24 \mathrm{~h} /$ week at $13 \mathrm{C}$} \\
\hline $\mathrm{I}(10 \%)$ & $47.6 \mathrm{a}-\mathrm{c}$ & $9.0 \mathrm{a}-\mathrm{c}$ & $2.3 \mathrm{~b}$ & $6.8 \mathrm{~b}-\mathrm{d}$ & $51.3 \mathrm{ab}$ & $3.4 \mathrm{a}$ & $1.4 \mathrm{a}$ \\
\hline$J(20 \%)$ & $48.9 \mathrm{ab}$ & $8.9 \mathrm{a}-\mathrm{c}$ & $2.4 \mathrm{ab}$ & $6.6 \mathrm{de}$ & $47.9 \mathrm{a}-\mathrm{c}$ & $2.3 \mathrm{~b}$ & $1.2 \mathrm{~b}$ \\
\hline
\end{tabular}

${ }^{2} \mathrm{SSC}=$ soluble solids concentration.

${ }^{y} \mathrm{D}=2$ cycles, 1 week $2 \mathrm{C}, 3$ weeks $13 \mathrm{C} ; \mathrm{E}=2$ cycles, 1 week $8 \mathrm{C}, 3$ weeks $13 \mathrm{C} ; \mathrm{F}=2$ cycles, 2 weeks $2 \mathrm{C}$, 2 weeks $13 \mathrm{C} ; \mathrm{G}=2$ cycles, 3 weeks $2 \mathrm{C}, 1$ week $13 \mathrm{C}$; $\mathrm{H}=2$ cycles, 3 weeks $8 \mathrm{C}, 1$ week $13 \mathrm{C}$.

${ }^{x}$ Percentage $(w / w)$ of juice to fresh weight.

"Mean separation in columns by Duncan's multiple range test, $\mathrm{P}<0.05$.

Spain (40 km from Crevillente), where they were kept at $13 \mathrm{C}$. The next day, the fruit were washed with water and dipped in thiabendazole at $2 \mathrm{~g} \cdot$ liter $^{-1}$ at $20 \mathrm{C}$ for $3 \mathrm{~min}$. Fruit of uniform size and appearance $(120 \mathrm{~g}, 60 \mathrm{~mm}$ in diameter, green-yellow, and free of defects) were randomized into 150 -fruit lots as three replicates of 50 fruit each per treatment. The plastic boxes containing the fruit were placed inside 360 -liter gas-tight chambers in cold storage rooms at 2,8 , or $13 \mathrm{C}$ with an $\mathrm{RH}>95 \%$ in each. The respective vapor pressure differences were $\leq 30,60$, and $80 \mathrm{~Pa}$.

The treatments were A) 8 weeks at 2C, B) 8 weeks at $8 \mathrm{C}, \mathrm{C}) 8$ weeks at $13 \mathrm{C}$, D) 1 week at $2 \mathrm{C}+3$ weeks at $13 \mathrm{C}+1$ week at $2 \mathrm{C}+3$ weeks at $13 \mathrm{C}, \mathrm{E}) 1$ week at $8 \mathrm{C}+3$ weeks at $13 \mathrm{C}+1$ week at $8 \mathrm{C}+3$ weeks at $13 \mathrm{C}, \mathrm{F}) 2$ weeks at $2 \mathrm{C}+2$ weeks at $13 \mathrm{C}+2$ weeks at $2 \mathrm{C}$ +2 weeks at $13 \mathrm{C}, \mathrm{G}) 3$ weeks at $2 \mathrm{C}+1$ week at $13 \mathrm{C}+3$ weeks at $2 \mathrm{C}+1$ week at $13 \mathrm{C}, \mathrm{H}) 3$ weeks at $8 \mathrm{C}+1$ week at $13 \mathrm{C}+3$ weeks at $8 \mathrm{C}$ +1 week at $13 \mathrm{C}$, I) $10 \% \mathrm{CO}_{2}$ for $24 \mathrm{~h}$ weekly during storage at $13 \mathrm{C}, \mathrm{J}) 20 \% \mathrm{CO}_{2}$ for $24 \mathrm{~h}$ weekly during storage at $13 \mathrm{C}$, and $\mathrm{K}$ ) $30 \%$ $\mathrm{CO}_{2}$ for $24 \mathrm{~h}$ weekly during storage at $13 \mathrm{C}$.

Physical and chemical analyses were performed on three 10-fruit samples at harvest and after each storage trial. Fruit were weighed with a precision of $\pm 0.01 \mathrm{~g}$ and weight loss was calculated as the percentage of initial fresh weight. Extractable juice obtained by squeezing was calculated as the percentage $(w / w)$ of juice to fresh weight. Juice was used to determine total soluble solids concentration (SSC), $\mathrm{pH}$, titratable acidity (TA), reducing and nonreducing sugars, and ascorbic acid. SSC was determined with an Abbé refractometer (readings at 20C). TA, calculated as the percentage of citric acid, was determined by titrating $1 \mathrm{ml}$ of juice with $0.1 \mathrm{~N} \mathrm{NaOH}$. Reducing and nonreducing sugars were determined using the method of Ting (1956). Ascorbic acid was determined by the Association of Official Analytical Chemists (AOAC, 1984) calorimetric method.

Carbon dioxide concentrations were obtained using calibrated capillaries, differential manometers, and gas mixers enriched with a known flow of compressed air. The gas flow was humidified in a mixer before entering the gas-tight chambers containing the fruit.

After they were removed from storage, all fruit were examined for decay and disorders.

Data were subjected to analysis of variance and means were separated by Duncan's multiple range test, where appropriate.

Juice composition of lemons stored for 8 weeks at $2 \mathrm{C}$ did not show any significant difference in constituents, except for a slightly lower nonreducing sugar content compared to fruit at harvest (Table 1). TA and nonreducing sugars decreased in lemons stored at 8 or $13 \mathrm{C}$ compared to fruit at harvest. No significant differences were evident between the latter two temperatures. Chemical composition of juice from lemons under intermittent warming was not different or only slightly different from fruit at harvest. Carbon dioxide promoted higher levels of reducing sugars, but nonreducing sugars were higher only in lemons treated with $10 \%$ and $20 \% \mathrm{CO}_{2}$ relative to

Table 2. Incidence of weight loss, decay, and physiological disorders of lemons after 8 weeks of storage under various conditions.

\begin{tabular}{|c|c|c|c|c|c|c|c|}
\hline \multirow[b]{2}{*}{ Treatment $^{2}$} & \multirow[b]{2}{*}{$\begin{array}{c}\text { Wt } \\
\text { loss (\%) }\end{array}$} & \multicolumn{6}{|c|}{ Decay and disorders (\% fruit affected) } \\
\hline & & Alternaria & $\begin{array}{c}\text { Red } \\
\text { blotch }\end{array}$ & Peteca & Membranosis & Pitting & Oleocellosis \\
\hline \multicolumn{8}{|c|}{ Cold storage } \\
\hline $\mathrm{A}(2 \mathrm{C})$ & $2.5 \mathrm{ab}^{y}$ & $0 \mathrm{c}$ & $0 \mathrm{~d}$ & $0 \mathrm{~b}$ & $32.6 \mathrm{C}$ & $4.0 \mathrm{a}$ & $31.3 \mathrm{a}$ \\
\hline B $(8 C)$ & $3.4 \mathrm{ab}$ & $0 \mathrm{c}$ & $9.3 \mathrm{c}$ & $0 \mathrm{~b}$ & $79.3 \mathrm{a}$ & $0.7 \mathrm{~b}$ & $0.7 \mathrm{~b}$ \\
\hline $\mathrm{C}(13 \mathrm{C})$ & $4.8 \mathrm{a}$ & $3.3 \mathrm{a}$ & $44.0 \mathrm{~b}$ & $0.7 \mathrm{~b}$ & $1.3 \mathrm{e}$ & $0 \mathrm{~b}$ & $0 \mathrm{~b}$ \\
\hline \multicolumn{8}{|c|}{ Intermittent warming } \\
\hline D & $3.1 \mathrm{ab}$ & $2.0 \mathrm{ab}$ & $35.3 \mathrm{~b}$ & $0 \mathrm{~b}$ & $12.7 \mathrm{de}$ & $2.7 \mathrm{~b}$ & $4.0 \mathrm{~b}$ \\
\hline E & $4.4 \mathrm{a}$ & $0.7 \mathrm{be}$ & $44.0 \mathrm{~b}$ & $0 \mathrm{~b}$ & $51.9 \mathrm{~b}$ & $0 \mathrm{~b}$ & $2.7 \mathrm{~b}$ \\
\hline $\mathrm{F}$ & $4.1 \mathrm{ab}$ & $0 \mathrm{c}$ & $7.3 \mathrm{c}$ & $0 \mathrm{~b}$ & $25.3 \mathrm{~cd}$ & $0 \mathrm{~b}$ & $0 \mathrm{~b}$ \\
\hline G & $1.4 \mathrm{~b}$ & $0 \mathrm{c}$ & $0 \mathrm{~d}$ & $4.0 \mathrm{a}$ & $52.6 \mathrm{~b}$ & $0.7 \mathrm{~b}$ & $3.3 \mathrm{~b}$ \\
\hline $\mathrm{H}$ & $1.6 \mathrm{~b}$ & $0 \mathrm{c}$ & $9.3 \mathrm{c}$ & $1.3 \mathrm{~b}$ & $81.0 \mathrm{a}$ & $2.7 \mathrm{~b}$ & $4.0 \mathrm{~b}$ \\
\hline \multicolumn{8}{|l|}{$\mathrm{CO}_{2}$ at $13 \mathrm{C}$} \\
\hline I $(10 \%)$ & $3.7 \mathrm{ab}$ & $2.7 \mathrm{a}$ & $70.1 \mathrm{a}$ & $0 \mathrm{~b}$ & $0 \mathrm{e}$ & $0 \mathrm{~b}$ & $0 \mathrm{~b}$ \\
\hline $\mathrm{J}(20 \%)$ & $1.6 \mathrm{~b}$ & $2.7 \mathrm{a}$ & $73.3 \mathrm{a}$ & $0 \mathrm{~b}$ & $0 \mathrm{e}$ & $\mathrm{Ob}$ & $0 \mathrm{~b}$ \\
\hline $\mathrm{K}(30 \%)$ & $3.3 \mathrm{ab}$ & $1.3 \mathrm{a}-\mathrm{c}$ & $84.0 \mathrm{a}$ & $0 \mathrm{~b}$ & $0 \mathrm{e}$ & $0 \mathrm{~b}$ & $0 \mathrm{~b}$ \\
\hline
\end{tabular}

${ }^{2} \mathrm{D}=2$ cycles, 1 week $2 \mathrm{C}, 3$ weeks $13 \mathrm{C}$; $\mathrm{E}=2$ cycles, 1 week $8 \mathrm{C}, 3$ weeks $13 \mathrm{C} ; \mathrm{F}=2$ cycles, 2 weeks $2 \mathrm{C}, 2$ weeks $13 \mathrm{C} ; \mathrm{G}=2$ cycles, 3 weeks $2 \mathrm{C}, 1$ week $13 \mathrm{C}$; $\mathrm{H}=2$ cycles, 3 weeks $8 \mathrm{C}, 1$ week $13 \mathrm{C}$.

'Mean separation in columns by Duncan's multiple range test, $P \leq 0.05$. 


\section{Literature Cited}

Engel, K.H. and R. Tressl. 1983. Formation of aroma components from nonvolatile precursors in passion fruit. J. Agr. Food Chem. 31:998.

Ettre, L.S. 1964. The Kovats retention index system. Anal. Chem. 36:31A.

Gebhardt, S.E., R. Cutrufelli, and R.H. Matthews. 1982. Composition of foods: Fruits and fruit juices: Raw, processed, prepared. U.S. Dept. Agr. Human Nuts. Info. Serv. Agr. Hdbk. 8-9. p. 268.

Idstein, H., W. Herres, and P. Schreier. 1984. Highresolution gas chromatography-mass spectrometry and. -fourier transform infrared analysis of cherimoya (Annona cherimola Mill.) volatiles. J. Agr. Food Chem. 2:383.

Idstein, H. and P. Schreier. 1985. Volatile components from guava (Psidium guajava, L.) fruit. J. Agr. Food Chem. 33:138.

MacLeod, A.J. and N.M. Pieris. 1981a. Volatile flavor components of soursop (Annona muricata). J. Agr. Food Chem. 29:488.

MacLeod. A.J. and N.M. Pieris. 1981b. Volatile flavor components of wood apple (Feronia limonia) and a processed product. J. Agr. Food Chem. 29:49.

MacLeod, A.J. and C.H. Snyder. 1985. Volatile components of two cultivars of mango from Florida. J. Agr. Food Chem. 33:380.

Morton, J.F. 1966. The soursop or guanabana $(A$ muricata L.J.). Proc. Fla. State Hort. Soc. 79:355.

Nishimura, O., K. Yamaguchi, S. Mihara, and T. Shibamoto. 1989. Volatile constituents of guava fruits (Psidium guajava L.) and canned puree. J. Agr. Food Chem. 37:139.

Paull, R.E. 1982. Postharvest variation in composition of soursop (Annona muricata L.) fruit in relation to respiration and ethylene production. J. Amer. Soc. Hort. Sci. 107:582.

Paull, R.E.,J. Deputy, and N.J. Chen. 1983. Changes inorganic acids, sugars, and headspace volatiles during fruit ripening of soursop (Annona muricata L.). J. Amer. Soc. Hort. Sci. 108:931.

Shibamoto, T. and C.S. Tang. 1990. 'Minor' tropical fruits-Mango, papaya, passion fruit, and guava, p. 221. In: I.D. Morton and A.J. MacLeod (eds.). Food flavors. Part C: The flavor of fruits. Elsevier Scientific Publishing Co., Amsterdam.

Shiota, H. 1978. Review and study on guava fruits flavor. Koryo 121:23.

Stein, S.E. 1987. NBS/EPA/MSDC mass spectral database. version 1.02. Office of Standard Reference Data, Natl. Bar. of Standards, Washington, D.C.

Takeoka, G., R.G. Buttery, R.A. Flath, R. Teranishi, E.L. Wheeler, R.L. Wieczorek, and M. Guentert. 1989. Volatile constituents of pineapple(Ananas comosus [L.] Merr.), p. 223. In: R. Teranishi, R.G. Buttery, and F. Shahidi (eds.).Flavorchemistry: Trends and developments. Amer. Chem. Soc., Washington, D.C.

Wenkam, N.S. and C.D. Miller. 1965. Composition of Hawaiian fruits. Hawaii Agr. Expt. Sta., Univ. of Hawaii. Bul. 135.

Wills, R. H. H., T.H. Lee, D. Graham, W.B. McGlasson, and E.G. Hall. 1981. Postharvest An introduction to the physiology and handling of fruits and vegetables. New S. Wales Univ. Press, Australia. 